\title{
PANGOLIN: "MISSING LINK OR INTERMEDIATE HOST" BETWEEN RESERVOIR HOST AND HUMAN POPULATION
}

\author{
Ashwini A Mankar \\ Assistant Professor \\ Department of Biotechnology \\ Kamla Nehru Mahavidyalaya, Nagpur
}

\begin{abstract}
Newly emerging viral diseases are major threats to public health. In particular, viruses from wildlife hosts have caused such emerging high-impact diseases as Severe Acute Respiratory Syndrome (SARS), Middle East Respiratory Syndrome (MERS), Ebola fever, Nipahvirus and Influenza in humans. The emergence of all these and many other human diseases occurred when an established animal virus switched hosts into humans and was subsequently transmitted within human populations, while host transfers between different animal hosts lead to the analogous emergence of epizootic diseases. The importance of viral host switching is underscored by the recent avian epizootics of high-pathogenicity strains of H5N1 influenza $A$, in which hundreds of "spillover" human cases and deaths have been documented which suggests that for the transmission of the virus, it definitely requires a possible intermediate host before it could infect human population (SPILLOVER) from its reservoir host containing many different types of viruses. In search of in search of intermediate host or source of COVID19 the latest candidate is the Pangolin, an endangered, scaly, ant eating mammal that is imported in huge numbers to Chinese markets for food and medicine. In this review we will see the reasons responsible for making the Pangolin as a link responsible for acting as an intermediate host.
\end{abstract}

Keywords: Spillover, Pangolin, Epizootic

\section{INTRODUCTION}

Pangolins, or scaly anteaters are mammals of the order Pholidota .The extant family, Manidae, has three genera: Manis, Phataginus and Smutsia. Manis comprises the four species found in Asia, while Phataginus and Smutsia each include two species living in Sub-Saharan Africa. [Gaudin, T. (2009)] These species range in size from 30 to $100 \mathrm{~cm}$ (12 to 39 in). The Malayan pangolin (Manisjavanica), a representative mammal species of the order Pholidota, is one of the only eight pangolin species worldwide. Four of them are from Asia (M. javanica, M. pentadactyla, M. crassicaudata and $M$. culionensis), whereas another four from Africa (M. tricuspis,

\author{
Vijay S Harode \\ Assistant Professor \\ Department of Biotechnology \\ Kamla Nehru Mahavidyalaya, Nagpur
}

M. tetradactyla, M. gigantea and M. temminckii) [Gaudin, et al. (2009)]. A number of extinct pangolin species are also known. As of January 2020, of the eight species of pangolin, three (Manisculionensis, M. pentadactyla and M. javanica) are listed as critically endangered, 3 are (Phataginustricuspis, Maniscrassicaudata and Smutsiagigantea) endangered and

(Phataginustetradactyla and Smutsiatemminckii) are listed as vulnerable on the Red List of Threatened Species of the International Union for Conservation of Nature.(Hance, J. (2014).

Pangolins have large, protective keratin scales covering their skin; they are the only known mammals with this feature. They live in hollow trees or burrows, depending on the species. Pangolins are nocturnal, and their diet consists of mainly ants and termites, which they capture using their long tongues.[Spearman, R.I.C. (2008), Wilson, A. E. (1994)]. They tend to be solitary animals, meeting only to mate and produce a litter of one to three offspring, which they raise for about two years. They certainly are one of the most trafficked mammals in Asia and, increasingly, Africa. Pangolins are in high demand in countries like China and Vietnam. Their meat is considered a delicacy and pangolin scales are used in traditional medicine and folk remedies. All eight pangolin species are protected under national and international laws. But there is still growing international illegal trade in pangolins. [Hance, J. (2014), Challender et al. (2019), Actman, J. (2015), Ingram et al. (2018)]

\section{- Genetic similarity: ENOUGH TO MAKE PANGOLIN AS THE CANDIDATE RESPONSIBLE FOR ACTING AS INTERMEDIATE HOST???}

As the virus is spreading around the world, it might find entirely new intermediate hosts outside of China. We don't know. "It is something every country needs to be thinking about as the epidemics wind down." Corona viruses are notoriously promiscuous. Bats host thousands of types without succumbing to illness, and the viruses have the potential to leap to new species (intermediate host). Sometimes they mutate along the way to adapt to their 


\section{International Journal of Engineering Applied Sciences and Technology, 2020 \\ Vol. 4, Issue 12, ISSN No. 2455-2143, Pages 440-442 \\ Published Online April 2020 in IJEAST (http://www.ijeast.com)}

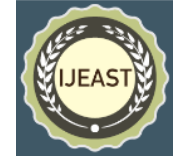

new host; sometimes they can make the leap without changing. One way virologists can try to predict potential host species is by using $3 \mathrm{D}$ computer modeling. For the virus to enter a cell to replicate, a spike-shaped protein it has must bind neatly with an enzyme receptor on the surface of certain animal cells, according to a recent discovery. The receptor, called an ACE2 protein, is the doorknob, and the spike protein is the key that unlocks it. Three-dimensional computer modeling can help figure out which animals have ACE2s that can be "unlocked" by the virus's spike protein. [Zhou et al. (2020)]

By comparing ACE2 receptors, a March 2020 study identified a number of species that the virus might be able to infect, including pangolins, cats, cows, buffalo, goats, sheep, pigeons, civets, and pigs.Another way scientists are searching for potential hosts is by exposing cells from various animals to the virus, to see which species can actually become infected.One recent experiment found that cells with ACE2 proteins from humans, pangolins, horseshoe bats, civets, and pigs could be infected with the virus, while mice could not. [Zhou et al. (2020), Wrong et al.(2004)]

Pangolins do play host to viruses that are similar to the new virus, known as SARS CoV-2 that causes the disease sweeping the globe.To confirm ourassumption, from the lung sample of Malayan Pangolins that were mapped to the SARSCoV-2 reference genome (GenBank:MN908947) [Wu et al. (2020)] and covered $76.02 \%$ of the SARS-CoV-2genome which showed genomic and evolutionary evidence of theoccurrence of a SARS-CoV-2-like CoV (namedPangolin$\mathrm{CoV}$ ) in dead Malayan pangolins. Pangolin-CoV is $91.02 \%$ and $90.55 \%$ identical to SARS-CoV-2and BatCoV RaTG13, respectively, at the whole-genome level.[Xiao et al.(2020)]Aside from RaTG13, Pangolin-CoV isthe most closely related $\mathrm{CoV}$ to SARS-CoV-2. The S1protein of Pangolin-CoV is much more closely relatedto SARS-CoV-2 than to RaTG13 But those viruses are not as close to the human virus as one called RaTG13, found in intermediate horseshoe bats.[Wrong et al.(2004), Wu et al. (2020), Xiao et al.(2020), Millet, J.K., Whittaker G.R. (2014)]. Some Pangolin-CoV genes showed higher amino acid sequence identity to SARSCoV-2 genes than to RaTG13 genes, including orf1b $(73.4 \% / 72.8 \%)$, the spike (S) protein $(97.5 \% / 95.4 \%)$, orf7a (96.9\%/93.6\%), and orf10 (97.3\%/94.6\%). The high S protein amino acid identity implies functional similarity between Pangolin-CoV and SARS-CoV-2.[Wrong et al.(2004),Lam et al. (2020), Xiao et al. (2020)]. Also Nucleic acid sequences of viruses taken from pangolins had initially been found to be a $99 \%$ match with SARS coronavirus 2 (SARSCoV-2), the virus which causes COVID-19, and responsible for the 2019-20 coronavirus pandemic.[Liu et al. (2019)].According to the above details provided it indicates that the Malayan pangolin might carry a novel $\mathrm{CoV}$ (here named Pangolin-CoV) that is similar to SARS-CoV-2 which would be responsible for confirming that Pangolins may be a potential candidate for acting as a missing link or intermediate host for SARS-CoV 2 OR COVID19.

None of those viruses are similar enough to the human virus to indicate a direct spillover to humans. And there has been no clear path established from bats to pangolins. It is still possible there could have been a direct leap from bats to humans, although that was not the case with earlier coronavirus outbreaks, like SARS and MERS.

\section{CONCLUSION}

Pangolins are the only mammals other than bats reported to date have been found to be infected with SARS-CoV2 related coronavirus. These findings highlight a potentially important role for pangolins in the ecology of coronaviruses, but do not directly implicate pangolins in the in the transmission of SARS-CoV2 which could state that they may be acting as an intermediate host. Neither would it be considered as link between reservoir host and humans just on the basis of genetic similarities in some regions or genome sequences when on comparison with some already known data. More findings need to be performed to clearly state that pangolins are the missing link or the intermediate host.

\section{REFERENCES}

1. Gaudin, T. (2009). "The Phylogeny of Living and Extinct Pangolins (Mammalia, Pholidota) and Associated Taxa: A Morphology Based Analysis" (PDF). Journal of Mammalian Evolution. Heidelberg, Germany: Springer Science+Business Media. 16 (4): pg 235-305. doi:10.1007/s10914-0099119-9.

2. Gaudin, T.J.; Emry, R.J.; Wible, J.R. (2009). The phylogeny of living and extinct pangolins (mammalia, pholidota) and associated taxa: A morphology based analysis. J. Mamm. Evol., 16, 235-305.

3. "Manidae Family search". IUCN Red List of Threatened Species. IUCN.Retrieved 30 January 2020.

4. Spearman, R.I.C. (2008)."On the nature of the horny scales of the pangolin". Zoological Journal of the Linnean Society.Oxfordshire, England: Oxford University Press. 46 (310): 267273. doi:10.1111/j.1096-3642.1967.tb00508.x

5. Wilson, A. E. (1994)."Husbandry of pangolins Manis spp". International Zoo Yearbook. 33 (1): $\quad$ 248-251. doi:10.1111/j.17481090.1994.tb03578.x 


\section{International Journal of Engineering Applied Sciences and Technology, 2020 \\ Vol. 4, Issue 12, ISSN No. 2455-2143, Pages 440-442 \\ Published Online April 2020 in IJEAST (http://www.ijeast.com)}

6. Hance, J. (2014). "Over a million pangolins slaughtered in the last decade".from the original on 8 December 2014. Retrieved 7 August 2014.

7. Challender, D.; Willcox, D.H.A.; Panjang, E.; Lim, N.; Nash, H.; Heinrich, S. \& Chong, J. (2019). "Manisjavanica".IUCN Red List of Threatened Species. IUCN. 2019: e.T12763A123584856.

8. Actman, J. (2015). "Crime Blotter: Pangolin Scales, Tiger Skins, and More". National Geographic.

9. Ingram, D. J.; Coad, L.; Abernethy, K. A.; Maisels, F.; Stokes, E. J.; Bobo, K. S.; Breuer, T.; Gandiwa, E.; Ghiurghi, A.; Greengrass, E.; Holmern, T. (2018). "Assessing Africa-Wide Pangolin Exploitation by Scaling Local Data: Assessing African pangolin exploitation". Conservation Letters. 11 (2): e12389. doi:10.1111/conl.12389

10. Zhou, P., Yang, X.-L., Wang, X.-G., Hu, B., Zhang, L., Zhang, W., Si, H.-R.,Zhu, Y., Li, B., Huang, C.-L., et al. (2020). A pneumonia outbreakassociated with a new coronavirus of probable bat origin. Nature.https://doi.org/10.1038/s41586-020-2012-7

11. Wrong, S.K.., Li, W.., M.J., Choe, H.., and Farzan, M.(2004).A 193-amino acid fragment of of SARS coronavirus $\mathrm{S}$ protein efficiently binds angiotensin converting enzyme 2.J.Chem.279,3197-3201

12. Wu, F., Zhao, S., Yu, B., Chen, Y.-M., Wang, W., Song, Z.-G., Hu, Y., Tao,Z.-W., Tian, J.-H., Pei, Y.Y., et al. (2020). A new coronavirus associatedwith human respiratory disease in China. https://doi.org/10.1038/s41586-020-2008-3

13. Xiao, K., Zhai, J., Feng, Y., Zhou, N., Zhang, X., Zou, J.-J., Li, N., Guo, Y.,Li, X., Shen, X., et al. (2020). Isolation and characterization of 2019-nCoV-like coronavirus from Malayan pangolins.doi: https://doi.org/10.1101/2020.02.17.951 335

14. Millet, J.K., Whittaker G.R. (2014).Host cell entry of Middle East respiratory syndrome coronavirus after two-step, furin-mediated activation of the spike protein Proc. Natl. Acad. Sci. USA, 111 (2014), pp. 15214-15219

15. Lam, T.T.-Y., Shum, M.H.-H., Zhu, H.-C., Tong, Y.G., Ni, X.-B., Liao, Y.-S., Wei, W. W., Cheung,Y. M., Li, W.-J., L.-F. Li, et al. (2020).Identification of 2019-nCoV related coronaviruses in Malayan pangolins in southern China.bioRxiv , 10.1101/2020.02.13.945485

16. Xiao, K., Zhai, J., Feng, Y., Zhou, N., Zhang, X., Zou, J.-J., Li, N., Guo, Y., Li, X., Shen, X., et al. (2020)Isolation and characterization of 2019-nCoVlike coronavirus from Malayan pangolins.bioRxiv , 10.1101/2020.02.17.951335.

17. Liu, P.; Chen, W.; Chen, J.-P.(2019). "Viral Metagenomics Revealed Sendai Virus and Coronavirus Infection of Malayan Pangolins(Manisjavanica)".Viruses. 11(11):979. doi:1 0.3390/v11110979. 